\title{
ANALISIS KELAYAKAN LOKASI BUDIDAYA METODE KARAMBA JARING APUNG DI PERAIRAN DESA PULAU HARAPAN SINJAI
}

\author{
Feasibility Analysis Location Of Floating Netting Karamba Method In Harapan Sinjai Island Village
}

\author{
Abdul Razak Yunus ${ }^{1}$, Sutia Budi ${ }^{2}$, Suryawati Salam ${ }^{3}$ \\ ${ }^{1}$ Dinas Kelautan dan Perikanan Kabupaten Sinjai \\ ${ }^{2}$ Program Studi Budidaya Perairan Universitas Bosowa \\ ${ }^{3}$ Program Studi Agribisnis Universitas Bosowa \\ Email : abdulrazakyunus0@gmail.com \\ Diterima : 08 Agustus 2019 \\ Dipublikasikan : 09 Desember 2019
}

\begin{abstract}
ABSTRAK
Penelitian ini bertujuan menganalisis tingkat kesesuaian perairan berdasarkan data parameter ekosistem perairan, mengetahui lokasi yang cocok untuk dikembangkan budidaya ikan kerapu dengan sistem karamba jaring apung yang berkelanjutan berdasarkan data parameter perairan yang meliputi kedalaman, kecerahan, kecepatan arus, salinitas, suhu, tinggi gelombang, derajat keasaman $(\mathrm{pH})$ dan oksigen terlarut dianalisis berdasarkan posisi koordinatnya. Hasil yang didapatkan Pada kelas S1, kawasannya mencakup area seluas \pm $467.898,82 \mathrm{~m} 2$ atau sebesar 26,47 \% dari total kawasan yang menjadi area studi. Kelas S2 mencakup area seluas $\pm 725.217,09 \mathrm{~m} 2$ atau sebesar 41,03\% dari luas kawasan yang menjadi area studi dari luas total perairan dan kelas S3, kawasannya mencakup area seluas \pm $574.609,54 \mathrm{~m} 2$ atau sebesar 32,51\% dari total kawasan yang menjadi area studi.
\end{abstract}

Kata Kunci: Ikan Kerapu, KJA, Kesesuaian Lahan, SIG

\section{ABSTRACT}

This study aims to analyze the suitability of water based on water ecosystem parameter data, find out suitable locations for grouper aquaculture development with a sustainable floating net karamba system based on water parameter data which includes depth, brightness, current speed, salinity, temperature, wave height, degree of acidity $(\mathrm{pH})$ and dissolved oxygen are analyzed based on the position of the coordinates. The results obtained in the S1 class, the area covers an area of $\pm 467,898.82 \mathrm{~m} 2$ or as much as $26.47 \%$ of the total area of study area. Class $S 2$ covers an area of $\pm 725,217.09 \mathrm{~m} 2$ or $41.03 \%$ of the area of the study area of the total area of waters and class $S 3$, the area covers an area of $\pm 574,609.54 \mathrm{~m} 2$ or $32.51 \%$ of the total area be a study area.

Keywords: Grouper, Water Suitability, Floating Cage, GIS

\section{PENDAHULUAN}

Kabupaten Sinjai secara morfologi daerah ini lebih dari 55,5\% terdiri dari daerah daratan tinggi dengan medan berbukit, bergelombang sampai bergunung, dan secara klimatologi terletak pada posisi iklim musim timur dimana bulan basah jatuh antara bulan April sampai dengan bulan Oktober dan bulan kering jatuh antara bulan Oktober sampai dengan bulan April. Dengan panjang garis pantai $\pm 41,06 \mathrm{~km}$ terdiri dari $\pm 23,7 \mathrm{~km}$ wilayah daratan dan $\pm 17,36 \mathrm{~km}$.

Pemanfaatan sumberdaya perairan laut di kawasan Pulau Harapan Kecamatan Pulau Sembilan yang dilakukan tidak terencana dan pengawasan yang kurang baik menyebabkan kondisi stok ikan mengalami kondisi tangkap lebih (overfishing), degradasi sumberdaya alam akibat pencemaran, penangkapan ikan dengan menggunakan bom dan bahan kimia, pengambilan karang yang berlebihan dan lain-lain. Kondisi seperti ini yang menyebabkan sebagian besar penduduk akan terperangkap dalam kemiskinan akibat produktivitas sumberdaya yang semakin berkurang dan terjadinya kerusakan lingkungan (Rudiyanto 2011).

Pulau Harapan menjadi perairan yang potensial untuk pengembangan budidaya laut terutama metode keramba jaring apung. Potensi budidaya laut tersebut sudah seharusnya dimanfaatkan dan dikelola dengan baik untuk peningkatan pendapatan dan kesejahteraan masyarakat secara berkelanjutan. Usaha perikanan budidaya yang dilaksanakan di perairan laut merupakan suatu kegiatan yang menawarkan kemungkinan kontinuitas produksi pangan yang kaya protein.

Desa Pulau Harapan adalah salah satu dari 4 desa yang ada di Kecamatan Pulau Sembilan Kabupaten Sinjai yang menjadi wilayah pesisir yang sangat potensial untuk dikembangkan budidaya perikanan khususnya budidaya laut dan salah satunya jenis ikan yang baik untuk dibudidayakan adalah jenis ikan kerapu (Epinephelus sp.). Spesies ini merupakan salah satu komoditas primadona karena bernilai ekonomis tinggi. Adapun produksi ikan kerapu hasil budidaya menjadi produk perikanan yang berkontribusi besat terhadap total produksi makanan ikan laut, FAO (2003) dalam Afero (2012).

Budidaya laut teknik keramba jaring apung menunjukkan perkembangan yang pesat. Di era otonomi daerah sekarang banyak kabupaten/kota, yang memiliki garis pantai, cenderung mengembangkan budidaya laut dengan teknik KJA (Subandar et al. 2004). Hal ini dimungkinkan oleh adanya dukungan teknologi baik perbenihan maupun pembesaran, pangsa pasar yang luas, harga jual yang cukup tinggi dibandingkan komoditas perikanan lainnya, ketersediaan lahan yang potensial, dan kebijakan pemerintah yang meletakkan subsektor 
perikanan budidaya menjadi prioritas utama dalam pembangunan perikanan ke depan. (Racmansyah 2004).

Keberadaan teluk dan pulau-pulau kecil yang ada, secara makro, sangat baik untuk kegiatan budidaya metode KJA karena posisinya yang terlindung dari ombak dan angin kencang. Perairan Pulau Sembilan merupakan tempat yang potensiai untuk dikembangkan budidaya laut dengan metode KJA. Kendala yang dihadapi untuk dapat mengembangkan budidaya laut metode KJA ini adalah belum tersedianya data dan informasi yang memadai mengenai lokasi yang sesuai dengan komoditas yang akan dibudidayakan serta kemampuan daya dukung lingkungan perairan dalam menopang kegiatan budidaya secara berkelanjutan.

\section{METODE PENELITIAN}

\section{Lokasi dan Jadwal Penelitian}

Penelitian ini dilaksanakan selama 2 bulan di Perairan Pulau Kambuno Desa Pulau Harapan Kecamatan Pulau Sembilan Kabupaten Sinjai Provinsi Sulawesi Selatan, yang dimulai pada bulan Juni 2019 - Juli 2019. Kegiatan ini meliputi tahapan studi pustaka, pengumpulan data baik primer maupun sekunder, penyusunan basis data, analisis data yang didapat dan penulisan laporan penelitian. Tahap pertama pengambilan data primer dilakukan pada tanggal 22 Juni 2019 dan dilanjutkan pada tanggal 23 Juni 2019 yang keduanya dilakukan pada saat akhir musim barat.

Pengambilan data primer pada tahap ke kedua dilakukan pada saat musim peralihan yaitu tanggal 06 Juli dan tanggal 07 Juli 2019. Setiap tahapan pengambilan data tersebut dilakukan pada saat pagi hingga sore hari. Sementara itu, untuk pengumpulan data sekunder dilakukan pada rentang waktu saat menunggu

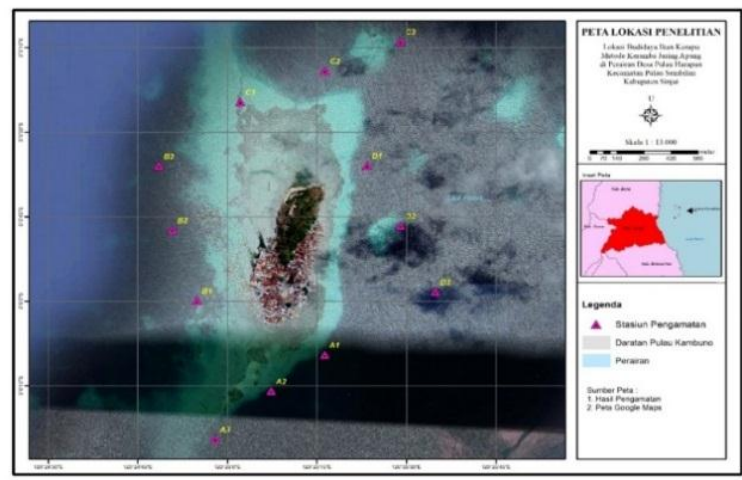

jadwal pengambilan data primer. Berikut Peta lokasi dan titik sampel penelitian dapat dilihat pada Gambar 1.

Gambar 1. Peta lokasi dan titik sampel penelitian Pulau Kambuno Desa Pulau Harapan.

\section{Bahan dan Data}

Bahan yang digunakan dalam penelitian ini adalah : Perairan Pulau Kambuno Desa Pulau Harapan. Koordinat batas wilayah penelitian yaitu : bagian Selatan $5^{\circ}$ 6'24.43"S GL - 120 24'57.95"T GB, bagian barat $5^{\circ}$ 5'35.96" GL - 120²4'48.53"T GB, bagian utara 5 $5^{\prime} 13.89^{\prime \prime} \mathrm{S}-120^{\circ} 25^{\prime} 29.02^{\prime \prime T}$ dan bagian timur $5^{\circ} 5^{\prime} 58.31^{\prime \prime S}$ Gl - $120^{\circ} 25^{\prime} 34.84^{\prime \prime T ~ G B . ~}$

Tahapan penelitian diawali dengan pengumpulan data spasial serta data pendukung lainnya, kemudian tahapan selanjutnya yaitu penyusunan basis data, dan tahap akhir berupa analisis data. Adapun data yang digunakan merupakan data sekunder. Pengamatan data primer di lapangan dilakukan sampling yang mewakili wilayah penelitian. Setiap lokasi pengamatan titik sampling dicatat posisi grografisnya dengan alat penentu posisi (GPS). Adapun jenis parameter dan alat yang digunakan dalam menunjang hasil pengukuran beberapa parameter fisika dan kimia dalam penelitian ini dapat dilihat pada Tabel 1.

Tabel 1. Alat Yang Digunakan dalam Penelitian analisis kelayakan lokasi budidaya ikan kerapu metode karamba jaring apung

\begin{tabular}{l|l|l}
\hline \multicolumn{1}{c|}{ Parameter } & Satuan & \multicolumn{1}{c}{ Alat yang digunakan } \\
\hline Kedalaman & $\mathrm{m}$ & water quality checker \\
\hline Kecerahan Air & $\%$ & water quality checker \\
\hline Suhu Perairan & ${ }^{\circ} \mathrm{C}$ & water quality checker \\
\hline Salinitas & $\mathrm{ppt}$ & water quality checker \\
\hline Kecepatan Arus & $\mathrm{m} / \mathrm{dt}$ & water quality checker \\
\hline $\mathrm{pH}$ & - & water quality checker \\
\hline Tinggi Gelombang & $\mathrm{m}$ & water quality checker \\
\hline Oksigen Terlarut & $\mathrm{m} / \mathrm{gl}$ & water quality checker \\
\hline Koordinat Lapangan & GL/GB & GPS \\
\hline
\end{tabular}

\section{Analisis Data}

\section{Analisis Kesesuaian Perairan untuk Budidaya Laut}

Untuk mendapatkan kelas kesesuaian maka di analisis kesesuaian perairan untuk parameter fisika-kimia oseanografi. Beveridge (1996) dalam Affan (2012) mengelompokkan faktor yang mempengaruhi budidaya menjadi dua yaitu faktor lingkungan meliputi kedalaman, kecerahan, kecepatan arus dan faktor kualitas perairan (suhu, salinitas, $\mathrm{pH}$, oksigen terlarut, fosfat, nitrat, nitrit, amoniak dan silikat).

Pengelompokan ini didasarkan atas pengaruh parameter, parameter dari faktor lingkungan akan mempengaruhi daya tahan hidup ikan laut sementara faktor kualitas akan mempengaruhi pertumbuhan, perkembangan dan daya tahan hidup ikan. Berikut syarat pembatas kehidupan dan perkembangan komoditas budidaya dan nilai parameter kesesuaian dapat dilihat pada Tabel 2.

Tabel 2. Nilai Kesesuaian Paraneter Perairan

\begin{tabular}{clccc}
\hline No. & \multicolumn{1}{c}{ Parameter } & $\begin{array}{c}\text { Sangat } \\
\text { sesuai } \\
(\mathrm{S} 1)\end{array}$ & $\begin{array}{c}\text { Cukup Sesuai } \\
(\mathrm{S} 2)\end{array}$ & $\begin{array}{c}\text { Tidak Sesuai } \\
(\mathrm{S} 3)\end{array}$ \\
\hline 1 & Kedalaman (m) & $10-15$ & $5-10 / 16-25$ & $<5 \mathrm{atau}>25$ \\
2 & Kec. Arus (m/s) & $0,2-0,5$ & $0,05-0,1$ & $>0,5 /<0,05$ \\
3 & Salinitas (ppt) & $30-35$ & $20-30$ & $<20 />35$ \\
4 & Kecerahan $(\%)$ & $79-100$ & $60-69$ & $<60$ \\
5 & Suhu $\left({ }^{\circ} \mathrm{C}\right)$ & $27-32$ & $20-26$ & $<20 />32$ \\
6 & pH & $7,5-8,7$ & $6,5-7,4$ & $<6,5 />8,7$ \\
7 & DO (mg/l) & $>7$ & $3-5 / 5-7$ & $<3$ \\
8 & Tinggi Gelombang & $0,2-0,3$ & $0,1-0,19 / 0,3$ & $<0,1 />0,4$ \\
\hline
\end{tabular}

Sumber: Sutaman (1993); Utojo dkk (2000); Sunyoto (1994); Djurjani (1999); Aslan (1998); Hidayat (1994) dalam Adibrata dkk (2007)

\section{Analisis Spasial}

Pada tahap analisis spasial data kualitas perairan dikumpulkan berasal dari titik sampling pengamatan, untuk menganalisis secara spasial, titik-titik tersebut terlebih dahulu dilakukan interpolasi. Beberapa metode untuk melakukan interpolasi diantaranya metode trend, spline, krigging dan Inverse Distance Weight, (IDW). 
Pengukuran dan analisis kualitas air pada masingmasing titik sampling, selanjutnya diolah dengan menggunakan software ArcGIS ini dilakukan interpolasi dengan metode IDW hingga menghasilkan layer data spasial masing-masing parameter kualitas perairan. Layer ini digunakan sebagai masukan untuk peta tematik untuk dioverlay, maka didapatkanlah peta lokasi yang layak untuk budidaya ikan kerapu berdasarkan interval kelas kesesuaian, pada lokasi yang layak ini selanjutnya dihitung luasannya.

\section{HASIL DAN PEMBAHASAN}

\section{Deskripsi Daerah Penelitian}

Perairan Pulau Kambuno merupakan Lokasi yang menjadi tempat penelitian penulis, yaitu terletak Desa Pulau Harapan di Kecamatan Pulau Sembilan Kabupaten Sinjai. Kecamatan ini berbatasan langsung dengan Perairan Kabupaten Bone dan Perairan Kabupaten Bulukumba. Secara admistrasi, terdapat dua pulau di Desa Pulau Harapan yaitu Pulau Kambuno dan Pulau Liang-liang serta terdapat beberapa gugusan yang sebagian besar menjadi lahan budidaya rumput laut.

Terumbu karang di perairan ini, dapat terlihat pada di kedalaman 2 hingga 4 meter. Letak lokasi penelitian jauh di sebelah timur bibir pantai Sinjai Utara (pelabuhan Larearea). Dari 4 desa yang berada di Kecamatan Pulau Sembilan ini, Desa Pulau Harapanlah yang memiliki penduduk paling besar yakni \pm 3500 Jiwa yang terbagi dalam empat dusun yaitu Liang-liang, Kambuno Timur, Kambuno Selatan, dan Kambuno barat sehingga ketika dilihat rumah penduduk tak jauh berbeda dengan rumah yang ada di Kota Kabupaten Sinjai yang sangat padat.

\section{Kesesuaian Lahan Perairan}

Pengukuran parameter fisik dan kimia dilakukan di Perairan Pulau Kambuno Desa Pulau Harapan pada beberapa titik, data yang telah menjadi lokasi pengambilan sampelnya. Adapun beberapa parameter yang telah menjadi fokus penelitian ini adalah kedalaman, kecerahan, kecepatan arus, salinitas, suhu, tinggi gelombang, derajat keasaman $(\mathrm{pH})$, oksigen terlarut.

Suhu Perairan

Menurut Evalawati (2001), suhu optimum untuk pertumbuhan ikan kerapu adalah 27 - 29 ${ }^{\circ}$. Suhu permukaan perairan hasil pengukuran dan analisa di perairan Pulau Kambuno Desa Pulau Harapan berada antara $24,12-30,7^{\circ} \mathrm{C}$. Hal ini menunjukkan suhu air di perairan Pulau Kambuno Desa Pulau Harapan Kecamatan Pulau Sembilan pada umumnya cocok untuk lokasi budidaya kerapu metode karamba jaring apung.

\section{Potential of Hydrogen $(\mathrm{pH})$}

Potential of Hydrogen $(\mathrm{pH})$ atau derajat keasaman merupakan konsentrasi ion hidrogen yang terdapat dalam air. Menurut Andriani (2004), derajat keasaman (pH) mempunyai pengaruh terhadap kehidupan tumbuhan dan hewan air sehingga sering dipergunakan sebagai petunjuk untuk menyatakan baik buruknya suatu perairan.

Sebaran derajat keasaman $(\mathrm{pH})$ perairan Pulau Kambuno Desa Pulau Harapan Kecamatan Pulau Sembilan Kabupaten Sinjai berkisar antara 6,17 - 8,85. Secara umum berdasarkan nilai pH perairan Pulau Kambuno Desa Pulau
Harapan Kecamatan Pulau Sembilan sesuai sebagai lokasi pengembangan budidaya ikan kerapu.

\section{Oxigen Terlarut (DO)}

Secara umum kandungan oksigen tersebut merata di beberapa titik sampling perairan Pulau Kambuno Desa Pulau Harapan dengan nilai oksigen terlarut antara 2,1 7,9 mg/l. Nilai tersebut menunjukkan perairan Pulau Kambuno Desa Pulau Harapan layak untuk dikembangkan menjadi lokasi budidaya kerapu karena masih berada pada ambang batas kesesuaian.

\section{Kedalaman}

Menurut Jumadi (2011), pada perairan yang dalam proses perencanaan budidaya akan kurang optimal, sebab konstruksi keramba jaring apung yang dibuat akan mengeluarkan biaya yang besar dalam proses pembuatannya.

Kedalaman perairan Pulau Kambuno Desa Pulau Harapan sangat berfariasi yakni dari kedalaman 2 hingga 15 meter. Kedalaman perairan yang sangat sesuai untuk lokasi budidaya kerapu terdapat di sisi barat dan timur Pulau Kambuno.

\section{Kecepatan Arus}

Pemilihan lokasi budidaya kerapu harus memperhatikan kecepatan arus permukaan. Arus permukaan yang terlalu kuat dapat mengakibatkan ikan yang dibudidayakan stress dan nafsu makan berkurang. Sebaliknya arus permukaan yang terlalu lemah dapat membuat berkurangnya sirkulasi oksigen. Affan (2012) melaporkan bahwa arus sangat berperan dalam sirkulasi air, selain pembawa bahan terlarut dan tersuspensi, arus juga mempengaruhi jumlah kelarutan oksigen dalam air.

Hasil penelitian kecepatan arus di Perairan Pulau Kambuno Desa Pulau Harapan, menunjukkan kecepatan arus bervariasi antara $0,05-0,7 \mathrm{~cm} / \mathrm{s}$. Kecepatan arus hampir merata disemua sisi Perairan Pulau Kambuno Desa Pulau Harapan Kecamatan Pulau Sembilan Kabupaten Sinjai.

\section{Salinitas}

Salinitas merupakan salah satu parameter yang memberikan pengaruh cukup besar dalam budidaya ikan kerapu macan. Salinitas merupakan parameter oseanografi penting yang bersama-sama dengan parameter lainnya untuk menduga kawasan yang sesuai untuk pertumbuhan ikan dan organisme akuatik lainnya (Hartami 2008).

Salinitas di perairan Perairan Pulau Kambuno Desa Pulau Harapan Kecamatan Pulau Sembilan Kabupaten Sinjai memiliki nilai yang bervariasi, hasil pengamatan menunjukkan nilai berada pada kisaran 26,2 - 36,8 Salinitas di perairan Kepulauan Sembilan menunjukkan bahwa wilayah ini mendapat pasokan air tawar yang sangat sedikit dan tidak berpengaruh banyak terhadap fluktuasi nilai salinitas.

\section{Kecerahan}

Pada penelitian ini, kecerahan merupakan salah satu parameter yang dapat memberikan pengaruh pada penentuan lokasi budidaya kerapu di Perairan Pulau Kambuno Desa Pulau Harapan. Kecerahan perairan suatu wilayah dipengaruhi oleh berbagai macam faktor, diantaranya keadaan cuaca, waktu pengukuran, kekeruhan 
perairan, padatan tersuspensi, plankton, dan partikel lumpur yang dibawa oleh aliran sungai dan batu-batuan.

Tingkat kecerahan yang tinggi akan sangat menentukan tingkat keberhasilan usaha budidaya kerapu. Berdasarkan hasil pengukuran di Perairan Pulau Kambuno Desa Pulau Harapan menunjukkan bahwa kecerahan yang hampir sama disemua titik lokasi sampling. Tingkat kecerahan terendah hingga mencapai $45 \%$ berada sebagian di sisi sebelah utara dan selatan Perairan Pulau Kambuno Desa Pulau Harapan.

\section{Tinggi Gelombang.}

Berdasarkan sifat-sifat gelombang, umumnya ditimbulkan oleh angin yang berasal dari arah timur laut, timur, dan tenggara. Pada pengukuran tinggi gelombang di Perairan Pulau Kambuno Desa Pulau Harapan diketahui bahwa tinggi gelombang di perairan tersebut berkisar antara $0,1 \mathrm{~m}-0,6 \mathrm{~m}$

\section{Sebaran Hasil Kesesuaian Perairan}

Peta hasil kesesuaian lahan budidaya di Perairan Pulau Kambuno Desa Pulau Harapan menunjukkan daerah yang sangat sesuai untuk budidaya ikan kerapu juga berada berada disekitar titik B1 namun tidak direkomendasikan untuk dijadikan lokasi budidaya ikan kerapu karena merupakan jalur pelayaran. Selanjutnya daerah yang direkomendasikan untuk dilakukan usaha budidaya adalah pada titik B2 dan B3 dan yang kedua ada pada sebelah timur yakni pada titik D1 dan D3 dan dari hasil informasi yang diperoleh kedua lokasi stasiun tersebut merupakan daerah yang cukup terlindung dari jalur pelayaran. Direktorat pembudidayaan (2013) merumuskan didalam petunjuk teknis budidaya ikan laut di jaring apung, salah satu syarat lokasi untuk budidaya ikan kerapu adalah tidak menghambat jalur pelayaran.

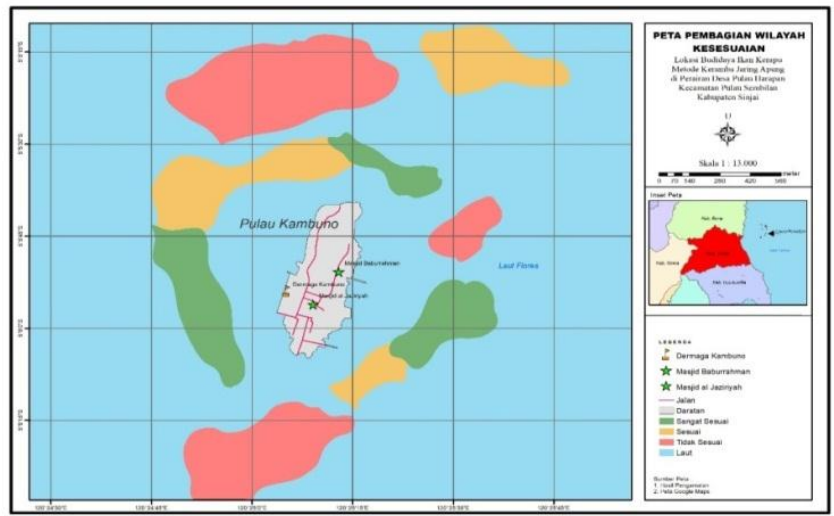

Gambar 2. Sebaran Nilai Kesesuaian Lahan Budidaya Ikan Metode KJA di Perairan Pulau Kambuno Desa Pulau Harapan.

Berdasarkan analisis data diperoleh wilayah Perairan Pulau Kambuno Desa Pulau Harapan yang termasuk dalam kategori sangat sesuai (S1) meliputi perairan di sisi barat dan timur Pulau Kambuno seluas $\pm 467.898,82 \mathrm{~m}^{2}$, yang termasuk dalam kategori sesuai (S2) meliputi sebagian wilayah barat, timur dan sebagian disisi sebelah utara Pulau Kambuno dengan luas $\pm 725.217,09 \mathrm{~m}^{2}$, sedangkan yang masuk dalam kategori tidak sesuai (S3) dari wilayah Perairan Pulau Kambuno Desa Pulau Harapan Kecamatan Pulau Sembilan Kabupaten Sinjai adalah seluas \pm $574.609,54 \mathrm{~m}^{2}$. Luas wilayah kesesuaian lahan untuk budidaya ikan kerapu metode keramba jaring apung di
Perairan Pulau Kambuno Desa Pulau Harapan Kecamatan Pulau Sembilan Kabupaten Sinjai dapat dilihat pada Tabel 3. berikut.

Tabel 3. Luas wilayah kesesuaian lahan untuk budidaya ikan kerapu metode karamba jaring apung di Perairan Pulau Kambuno Desa Pulau Harapan

\begin{tabular}{cccc}
\hline No & Keterangan Kelas & Luas m2 & Prosentase (\%) \\
\hline 1 & S1 & $467.898,82$ & 26,47 \\
2 & S2 & $725.217,09$ & 41,03 \\
3 & S3 & $574.609,54$ & 32,51 \\
\hline & Total & $\mathbf{1 . 7 6 7 . 7 2 5 , 4 5}$ & $\mathbf{1 0 0}$ \\
\hline
\end{tabular}

Kesesuaian lahan untuk budidaya budidaya ikan kerapu di metode keramba jaring apung di Perairan Pulau Kambuno Desa Pulau Harapan Kecamatan Pulau Sembilan Kabupaten Sinjai berdasarkan tabel diatas dapat diketahui bahwa wilayah yang layak dan potensi untuk dikembangkan menjadi lokasi budidaya ikan kerapu metode keramba jaring apung secara keseluruhan adalah seluas $1.193 .115,91 \mathrm{~m}^{2}$. Dari total luas wilayah penelitian sebesar $1.767 .725,45 \mathrm{~m}^{2}$

\section{KESIMPULAN}

Hasil penelitian didapat bahwa Hasil analisis kondisi fisik dan kimia Perairan Kambuno Desa Pulau Harapan Kecamatan Pulau Sembilan di seluruh stasiun pengamatan memperlihatkan kesesuaian wilayah bagi pertumbuhan ikan yang akan dipelihara khususnya untuk kegiatan budidaya ikan dengan sistem keramba jaring apung. Lokasi yang sesuai untuk budidaya KJA kerapu berada pada titik B1 dan B2 stasiun 2 di sebelah barat pulau serta titik D2 dan D3 stasiun 3 di sebelah timur pulau. Sedangkan titik yang tidak sesuai berada pada semua titik di stasiun sebelah utara dan selatan pulau. Dari penelitian yang dilakukan didapat tiga kelas kesesuaian lahan untuk budidaya ikan dengan sistem keramba jaring apung. Pada kelas S1, kawasannya mencakup area seluas \pm 467.898,82 m2 atau sebesar 26,47 \% dari total kawasan yang menjadi area studi. Kelas S2 mencakup area seluas $\pm 725.217,09 \mathrm{~m} 2$ atau sebesar 41,03\% dari luas kawasan yang menjadi area studi dari luas total perairan dan kelas S3, kawasannya mencakup area seluas $\pm 574.609,54 \mathrm{~m} 2$ atau sebesar $32,51 \%$ dari total kawasan yang menjadi area studi.

\section{DAFTAR PUSTAKA}

Adibrata S. 2012. Evaluasi Kesesuaian Kawasan Untuk Pengembangan Budidaya Kerapu (Famili Serranidae) di Perairan Pulau Pongok Kabupaten Bangka Selatan. Tesis. Sekolah Pascasarjana, Institut Pertanian Bogor. Bogor. (Tidak dipublikasikan).

Afero F. 2012. Analisa ekonomi budidaya kerapu macan (Epinephelus fuscoguttatus) dan kerapu bebek (Cromileptes altivelis) dalam keramba jaring apung di Indonesia. Jurnal Depik 1(1):10-21.

Affan JM. 2012. Identifikasi lokasi untuk pengembangan budidaya keramba jaring apung (KJA) berdasarkan faktor lingkungan dan kualitas air di perairan Pantai Timur Bangka Tengah. Jurnal Depik 1(1):78-85.

Alexander Leonidas Kangkan. 2006. Studi Penentuan Lokasi Untuk Pengembangan Budidaya Laut 
Berdasarkan Parameter Fisika, Kimia Dan Biologi Di Teluk Kupang, Nusa Tenggara Timur. Universitas Diponegoro Semarang

Badan Pusat Statistik. 2011. Kabupaten Sinjai Dalam Angka Tahun 2010. Badan Pusat Statistik Kabupaten Sinjai. Balangnipa.

Boggs, S. Jr. 2009. Petrology of sedimentary rocks, 2nd ed. Cambridge University Press.

Damai. 2015. Analisis Daya Dukung Perairan Puhawang Untuk Kegiatan Budidaya Sistem Karamba Jarring Apung. Aquasains J. Ilmu Perikanan dan Sumberdaya Perairan, 3(2):259- 264.

Deniel Zefriza. 2014. "Analisis Spasial Kesesuaian Budidaya Ikan Kerapu (Epinephelus sp) dengan Unit Keramba Jaring Apung (KJA) di Perairan Lhok Bubon Aceh Barat"., 3(2):259- 264.

Ghani, A. A., Hartoko. R., Wisnu. 2015. Analisa Kesesuaian Lahan Perairan Pulau Pari Kepulauan Seribu Sebagai Lahan Budidaya Ikan Kerapu (Epinephelus Sp.) Pada Keramba Jaring Apung Dengan Menggunakan Aplikasi SIG. Journal of Aquaculture Management and Technology. 4 (1), 54-61.

Hartami P. 2008. Analisis Wilayah Perairan Teluk Pelabuhan Ratu untuk Kawasan Budidaya Perikanan Sistem Keramba Jaring Apung. Tesis. Sekolah Pascasarjana, Institut Pertanian Bogor. Bogor. (Tidak dipublikasikan).

Hartoko A. dan Alexander K. 2009.Spasial Modeling For Marine Culture Site Selection Based On Ecosystem Parameters At Kupang Bay, East Nusa TenggaraIndonesia. International Journal of Remote Sensing and Earth Science.ISSN : 0216-6739. VOL 6.pp: 57 - 64.

Hasnawi. A., Mustafa. M., Paena. 2011. Evaluasi Kesesuaian Lahan Untuk Budidaya Ikan Dalam Keramba Jaring Apung Di Perairan Pesisir Kabupaten Mamuju Provinsi Sulawesi Barat. Jurnal Riset Akuakultur 6 (1), 157-167.

Hasnawiya. 2012. Studi Kesesuaian Lahan Budidaya Ikan Kerapu Dalam Karamba Jaring Apung Dengan Aplikasi Sistem Informasi Geografis di Teluk Raya Pulau Singkep, Kepulauan Riau. Journal Of Aquaculture Management and Technology, 1(1) : 87-101.

Heriansahdan Fadly Anggriawan. 2012. Penentuan Kesesuaian Lokasi Keramba Jaring Apung Kerapu (Epinephelus Spp) Melalui Sistem Informasi Geografis Di Pulau Saugi Kabupaten Pangkep Provinsi Sulawesi Selatan. Balik Diwa Makassar

Jumadi W. 2011. Penentuan Kesesuaian Lahan Keramba Jaring Apung Kerapu Macan (Epinephelus Fuscogutattus) Menggunakan Sistem Informasi Geografis Di Pulau Panggang Kepulauan Seribu. Skripsi. Institut Pertanian Bogor. Bogor. (Tidak dipublikasikan).

KKP Dirjen Perikanan Budidaya. 2011. Profil Ikan Kerapu Indonesia. Direktorat Produksi. Jakarta, $133 \mathrm{hlm}$.

KLH. 2004. Salinan Surat Keputusan Menteri Negara Lingkungan Hidup Nomor 51 tahun 2004 tentang Baku Mutu Air Laut.

Kordi, M.G.K., 2011. Marikultur Prinsip dan Praktik Budidaya Laut, 1st ed. Penerbit ANDI, Yogyakarta. p 616.
Landau, M. 1995. Introduction to Aquaculture. John Willey \& Sons, Inc. New York. Pgs 440.

Langkosono dan Wenno, L. F. 2003. Distribusi Ikan Kerapu (Serranidae) dan Kondisi Lingkungan Perairan Kecematan Tanimbar Utara, Maluku Tenggara. Prosiding Lokakarya Nasional dan Pameran Pengembangan Agribisnis Kerapu II Jakarta, 8 - 9 Oktober 2002. ". Menggalang Sinergi untuk Pengembangan Agribisnis Kerapu” .Pusat Pengkajian dan Penerapan Teknologi Budidaya Pertanian BPPT, Jakarata. $203-212$.

Loka, J., Vaidya, N.G., Philipose, K.K., 2012. Site and species selection criteria for cage culture, in: Philipose, K.K., Loka, J., Sharma, S.R.K., Damodaran, D. (Eds.), Handbook on Open Sea Cage Culture. Central Marine Fisheries Research Institute, Calicut, India, p. 143.

Mayunar, Purba R, Imanto PT. 1995. Pemilihan Lokasi Budidaya Ikan Laut in Prosiding Temu Usaha Pemasyarakatan Teknologi Keramba Jaring Apung Bagi Budidaya Laut. Badan Litbang Pertanian, Jakarta. pp. 179-189.

Muawanah, N. Sari, A. Triana K. dan Hendrianto. 2004. Kelimpahan Plankton Penyebab Red Tide Pyrodinium bahamense di Teluk Hurun, Lampung Selatan. Buletin Teknik Litkayasa Akuakultur Vol. 3 No. 2. p 1-5.

Maududijmal Rahim. 2013. Penentuan Lokasi Budidaya Kerapu Macan (Epinephelus Fuscoguttatus) Menggunakan Sistem Informasi Geografis. Departemen Ilmu Dan Teknologi Kelautan Fakultas Perikanan Dan Ilmu Kelautan Institut Pertanian Bogor 2013.

Meriyanti Ngabito Dan Nurul Auliyah. 2018. Kesesuaian Lahan Budidaya Ikan Kerapu (Epinephelus Sp.) Sistem Keramba Jaring Apung Di Kecamatan Monano. Fakultas Pertanian Universitas Gorontalo. 